\title{
(5)

\section{Hva kompleksitetsteori kan lære oss om sykdom og organisering}

KRONIKK

\section{LARS PRAG ANTONSEN}

E-post: larspantonsen@hotmail.com

Lars Prag Antonsen er lege i spesialisering i anestesi ved Oslo universitetssykehus, Ullevål og ved Sykehuset Østfold.

Forfatter har fylt ut ICMJE-skjemaet og oppgir ingen interessekonflikter.

Trekkfuglers bevegelsesmønstre, kinesisk krigsfilosofi og klassisk musikk kaster nytt lys over hvordan vi forstår biologiske og organisatoriske systemer. Kompleksitetsteori forklarer komplekse adaptive systemer og er nyttig både som grunnleggende filosofi og som praktisk klinisk hjelpemiddel.

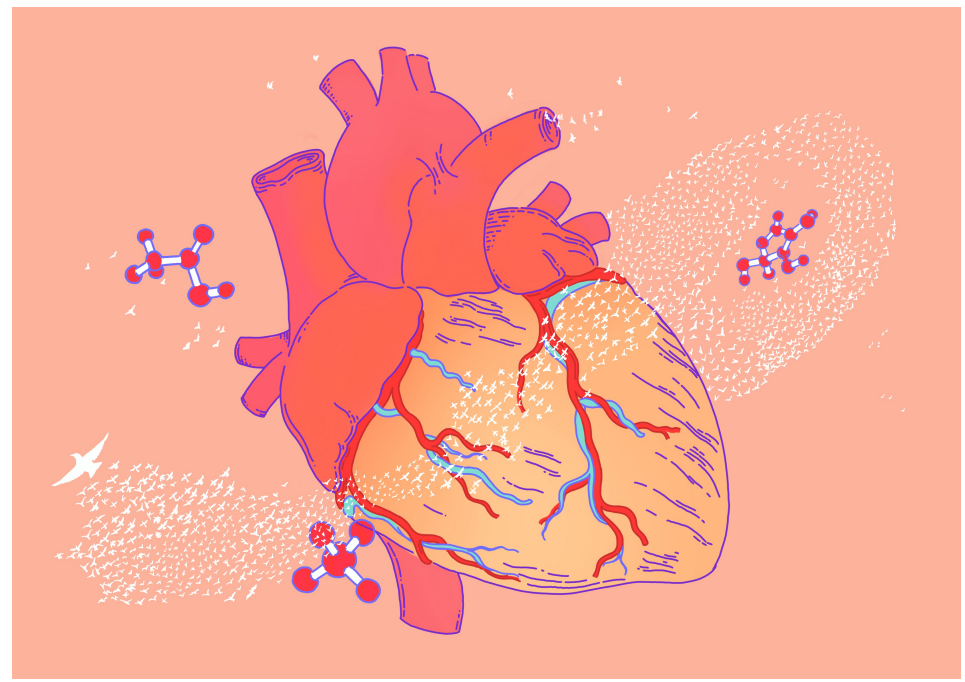

Illustrasjon: Sylvia Stølan

Medisinsk vitenskap omhandler komplekse systemer i hele spekteret fra molekylærbiologi til sykehusorganisering. Slike systemer kan ikke alene forstås med reduksjonistiske forklaringsmodeller basert på mekanistiske og deterministiske årsaksforhold. Kompleksitetsteori representerer et nytt tankesett som svarer på disse utfordringene (1).

Nøyaktig diagnostikk, korrekt behandling og presise prognoser er avgjørende for god pasientbehandling. Organisatorisk forståelse og økonomisk innsikt er hjørnesteiner i god helseledelse. Et godt helsevesen forutsetter inngående kunnskap om disse systemene. For eksempel hjelper hemodynamiske modeller oss å forstå hvordan vi bedrer hjerteminuttvolum hos kritisk syke; kunnskap om immunsystemet kan gjøre det mulig å forutsi hvordan infeksjonen utvikler seg hos en pasient med alvorlig sepsis; biokjemisk og 
farmakologisk kunnskap er nødvendig for å utvikle effektive medisiner; psykologisk innsikt fremmer samarbeid i avdelingen og bidrar til effektiv organisering; akademisk metodikk er grunnlaget for forskning og kvalitetsforbedrende arbeid; og ledelsesteori forteller oss hvordan avdelingen eller skadestedet bør organiseres. Et spørsmål forblir likevel ubesvart: Hvor godt forstår vi egentlig disse systemene? Kompleksitetsteori beskriver sammenhenger der tradisjonelle metoder er utilstrekkelige.

\section{Hva er kompleksitetsteori?}

Kompleksitetsteori (complexity science) er et samlebegrep for teorier som beskriver komplekse systemer. Den sentrale ideen er at systemer skal forstås som en helhet. Et system kan ikke forklares ved å studere enkeltkomponentene isolert, slik tradisjonell reduksjonistisk metode ofte gjør. Innen kompleksitetsteori er man opptatt av egenskaper ved samspillet og interaksjonene i systemet, mer enn av egenskapene til enkeltdelene (1). Kompleksitetsteori har røtter i generell systemteori og omfatter blant annet kaosteori (1).

Hovedkomponenten i kompleksitetsteori kalles et komplekst adaptivt system. Et klassisk bilde av et komplekst adaptivt system, og et godt utgangspunkt for å forstå teorien, er følgende: Se for deg en enorm fugleflokk - tusenvis av individer - fly over himmelen. Den bølger frem og tilbake som en gigantisk gardin og deles i mindre enheter for å unngå hindringer før den samles igjen. Fugleflokken utgjør et system fordi den består av aktører som interagerer med hverandre. Den er kompleks fordi aktørene er mange og fordi den beveger seg i uforutsigbare mønstre. Den er adaptiv fordi den er robust og tilpasser seg påvirkning fra omgivelsene.

Betyr det at kompleksitetsteori først og fremst er interessant for ornitologer? Heldigvis ikke. Kompleksitetsteori er relevant for de fleste vitenskapelige disipliner. Den utgjør et omfattende rammeverk av begreper, teoretiske beskrivelser, matematiske modeller og praktiske verktøy til bruk i klinisk praksis, forskning og ledelse (1). Den har gitt ny forståelse av systemer så (tilsynelatende) forskjellige som nevronale nettverk, hjertefysiologi, sepsis, intensivbehandling, helsetjenesteorganisering, global økonomi, ledelsesfilosofi og organisasjonspsykologi - for å nevne noen (1).

\section{Systemets egenskaper}

Komplekse adaptive systemer har karakteristiske egenskaper. For det første er de ofte selvorganiserende. Selvorganisering er en prosess der det spontant oppstår orden og funksjon i et system uten overordnet kontroll, som når fugleflokken fungerer uten en bestemt leder. Tilsvarende mekanismer ser vi i maurkolonier, i sosiale medier eller i organisasjoner der det oppstår samarbeid og nettverk på tvers av formelle strukturer (1).

Kompleksitetsteoretikeren Stuart Kauffman trekker i boken Origins of order resonnementet enda lenger (2): Kanskje livet selv er et resultat av selvorganisering? Atomer og molekyler interagerer basert på ladning og størrelse. De danner forbindelser med kompleks struktur og funksjon. Eksempelvis organiseres fosfolipider til cellemembraner og muliggjør kjemiske reaksjoner med økende kompleksitet: metabolisme, DNA-replikasjon, celledeling og organutvikling. I en større organisme oppstår koagulasjonskaskader, immunresponser og nevronale nettverk på tilsvarende måte. Nevronale nettverk i sentralnervesystemet er fysisk substrat for bevissthet og atferd som fremmer sosial interaksjon, ny DNA-replikasjon og omsorg for avkom. Kauffman oppsummerer det slik:

"The origin of life, rather than having been vastly improbable, is instead an expected collective property of complex systems of catalytic polymers and the molecules on which they act. Life, in a deep sense, crystallized as a collective self-reproducing metabolism in a space of possible organic reactions. If this is true, then the routes to life are many and its origin is profound yet simple.» (1, s. 285).

For det andre har slike systemer egenskaper som ikke kan forklares ved kun å analysere enkeltkomponentene (emergent properties). Fugleflokkens bevegelsesmønster oppstår fra 
interaksjoner mellom fuglene og kan ikke forklares ved å studere individene isolert. Tilsvarende er hjernens struktur og elektrokjemiske virkemåte godt beskrevet. Likevel vet vi lite om hvordan vår opplevelse av bevissthet oppstår. Innovative organisasjoner skaper overraskende løsninger vi ikke kan forutse ut fra gruppens sammensetning. Det fantastiske fargespillet i et vakkert maleri er et resultat av få basisfarger i riktig kombinasjon. Et flott musikkstykke oppstår i harmonier mellom et lite antall grunntoner. Og selv om analyse av kunstnerens komposisjon og teknikk er spennende, kommer man sjelden nærmere selve kjernen: Hvorfor oppleves dette så fantastisk? Det er en viktig påminnelse om at helheten i et system er mer enn summen av delene.

For det tredje fungerer systemet best på grensen mellom orden og kaos (edge of chaos). Et system i komplett orden er stabilt og forutsigbart, men rigid og uten evne til fleksibel tilpasning. Et system i kaos er ustabilt og upålitelig. Midt imellom finner vi systemer i riktig balanse. I en slik fugleflokk er interaksjonen sterk nok til å holde fuglene samlet, men løs nok til å opprettholde fleksibilitet. På samme måte må et effektivt immunforsvar balansere på grensen mellom orden og kaos. Det må være fleksibelt nok til å reagere på et stort antall ukjente antigener, men uten å bli aktivert av kroppens egne strukturer. Et ineffektivt og rigid system (som ved immunsuppresjon) er like uhensiktsmessig som et ustabilt og kaotisk system (som ved autoimmun sykdom). Kompleksitetsteoretisk tilnærming til slik dysregulering kan gi ny forståelse av kroppens respons ved sepsis og autoimmune sykdommer (1).

Forståelsen av at effektive organisasjoner balanserer mellom orden og kaos, er ikke ny. President John F. Kennedy ble etter hvert kjent for aktivt å dyrke motstridende meninger til gruppens beste. Han forsto at effektive organisasjoner vokser på konstruktiv uenighet, og la til rette for dette i sin stab (3). Den kinesiske generalen og filosofen Sun Tzu (544-496 f.Kr.) beskrev for over to tusen år siden hvordan små, selvstyrte grupper av krigere kan utmanøvrere en langt sterkere fiende. Han forsto at ønsket om kontroll virket mot sin hensikt og ga derfor soldatene stort handlingsrom. Han vektla betydningen av å legge fleksible planer og at ledere må akseptere usikkerhet (4). Dette er fortsatt bærende prinsipper i operativ ledelse og kan danne grunnlag for hvordan vi utformer beredskapsplaner eller organiserer et uoversiktlig skadested (5). De to kjente neppe til kompleksitetsteori, men de viste stor kunnskap om hvordan mennesker fungerer sammen i komplekse adaptive systemer. Kompleksitetsteori postulerer derfor at robuste, fleksible og effektive systemer fungerer best på grensen av kaos.

For det fjerde har systemet ofte fraktalmønstre. Fraktaler er mønstre som er (tilnærmet) identiske på mikroskopisk og makroskopisk nivå i samme system. Fraktaler er termodynamisk stabile strukturer og eksisterer overalt i naturen. Snøkrystaller, elvedelta, bølger, bronkialtreet, koronararterier og purkinjefibre er geometriske fraktaler. Tidsintervaller og variabilitet i hjertefrekvens og EEG-signaler er statistiske fraktaler (1).

\section{Menneskekroppen som komplekst adaptivt system}

Så hvilken nytte har vi av å beskrive menneskets fysiologi - samspillet mellom nerveforbindelser, immunforsvar, organsystemer og hormoner - som et komplekst adaptivt system?

Hos friske mennesker varierer hjertefrekvens, respirasjonsfrekvens, EEG-signaler, blodsukkernivå, hormonnivåer, blodtrykk og korrelasjonen mellom dem i komplekse fraktalmønstre. Hos syke avtar denne kompleksiteten. Komplekse mønstre er altså et uttrykk for at organismen er frisk, mens avtagende kompleksitet er et tidlig tegn på sykdom (1).

Slike patofysiologiske forandringer er påvist ved en rekke tilstander (1): Lav pulsvariabilitet predikerer dødelighet og oppstår før EKG-forandringer og troponinutslipp ved hjerteinfarkt. Manglende korrelasjon mellom vitale parametre predikerer forverring ved traumer, sepsis og brannskader. Hos pasienter med diabetes er det vist at variabilitet $\mathrm{i}$ 
blodsukkernivå mister kompleksitet i tiden før sykdommen manifesterer seg. Tilsvarende tap av kompleksitet oppstår i EEG-mønstre hos pasienter med psykiske lidelser. Hos eldre avtar fraktalmønstre i nevronaktivitet og hormonfrigjøring, mens tap av trabekelverk i skjelettet og av alveoler i lungene representerer tap av geometriske fraktalmønstre (1).

Dette kan ha konsekvenser for hvordan vi behandler syke. Ved å forstå pasienten som et komplekst adaptivt system postulerer vi at pasientens fysiologiske mønstre viser nettopp lav variabilitet og tap av fraktalmønster. God behandling forsøker å gjenopprette normal fysiologi.Vi fingransker blodtrykksvariasjoner, respirasjonsfrekvens, timediurese og temperatursvingninger. Vi gir medikamenter, væske og ernæring i finjusterte doser og detaljstyrer innstillingene på respiratoren. Kan det tenkes at overdreven regelmessighet motvirker fysiologisk (høy) variabilitet og dermed forlenger sykdomsprosessen? Enkelte studier antyder nettopp dette (1). Begreper som variabilitet og fraktalmønster kan virke abstrakte, men med riktig teknologi er det ukomplisert å måle variabilitet i hjertefrekvens, respirasjonsmønster og EEG-signaler og å vise dette som tallverdier på monitoren over pasientens seng - til nytte i det daglige kliniske arbeidet.

\section{Helsevesenet som komplekst adaptivt system}

Også sykehus eller andre store organisasjoner i helsevesenet forstås som komplekse adaptive systemer (1). Et sykehus består av et stort antall ansatte, pasienter og pårørende som interagerer i nettverk av formelle og uformelle strukturer, bekjentskaper, møter, konsultasjoner, telefonsamtaler og journalnotater. Kompleksitetsteori systematiserer kunnskap fra ledelses- og organisasjonsteori, kvalitetsforbedringsarbeid og konflikthåndtering. I kombinasjon kan slik kunnskap gi økt forståelse av hvordan vi bygger gode og effektive organisasjoner (1).

Tradisjonell organisasjonsteori vektlegger formell struktur, rasjonalisering og standardisering (1). Den bygger på antagelsen om at detaljerte planer, toppstyrt kontroll og analyser kan forutsi fremtidige resultater. Organisasjonen betraktes som en maskin der like startverdier gir samme resultat hver gang. Uenighet betraktes som en forstyrrelse som bør tones ned. Feil forhindres best gjennom forbud, standardiserte prosedyrer eller ved å endre på enkeltfaktorer. Et slikt syn på feil og avvik kan gi grobunn for en kultur der frykten for å feile overskygger gleden av å lykkes. Dermed øker risikoen for nye feil.

Kompleksitetsteori understøtter moderne ledelses- og organisasjonsteori. Den tilstreber fleksibilitet, handlefrihet og desentralisert lederskap (1). Formell struktur tillegges mindre betydning. Organisasjonen er en dynamisk enhet i stadig endring. Planverk er fleksible og tilstreber balanse mellom detalj- og intensjonsstyring. Samhandling oppstår på tvers av avdelinger og i tilfeldige fora. Uenighet er sunt og er - med rett håndtering - kilde til ny kunnskap.

Det er naturligvis naivt å sette opp et skarpt skille mellom to slike spissformulerte tilnærminger. Handlefrihet og fleksibilitet må aldri utelukke tydelig lederskap og målrettet organisering når det er påkrevd. Overordnede prioriteringer, økonomiske rammer, verdigrunnlag og langsiktig strategi må styres sentralt -ikke minst av demokratiske årsaker. Kompleksitetsteori har på langt nær alle svar, men gir verdifulle innspill til hvordan vi kan organisere helsevesenet enda bedre.

\section{Veien videre}

God pasientbehandling og god helseledelse - et godt helsevesen - krever at vi har god kunnskap om komplekse adaptive systemer i hele spekteret fra molekylærbiologiske reaksjoner til sykehusorganisering. Kompleksitetsteori beskriver slike systemer med nye forklaringsmodeller der tradisjonell, reduksjonistisk metodikk er utilstrekkelig. Internasjonalt omtales kompleksitetsteori som en ny og sentral vitenskapelig idé (1). Noen hevder kompleksitetsteori kun setter fine ord på fenomener som kloke mennesker har beskrevet i århundrer (6). Slike fremstillinger har dessverre skapt et unyansert bilde av hva 
dette fagfeltet egentlig er. I moderne kompleksitetsteori vektlegges praktisk nytteverdi, matematiske verktøy og klinisk relevans. I riktig kombinasjon utgjør kompleksitetsteori en grunnleggende filosofi, et teoretisk rammeverk og et praktisk verktøy til bruk i ledelse, forskning og daglig klinisk arbeid.

LITTERATUR:

1. Sturmberg J, Martin C. Handbook of systems and complexity in health. New York, NY: SpringerVerlag, 2013.

2. Kauffman S. Origins of order. Self-organization and selection in evolution. Oxford: Oxford University Press, 1993.

3. Dallek R. An unfinished life: John F. Kennedy, 1917-1963. Boston, MA: Little, Brown and Company, 2003.

4. Sun Tzu. The art of war.

5. Johannesen SO. Strategies, leadership and complexity in crisis and emergency operations. New York, NY: Taylor \& Francis Ltd, 2017.

6. Reid I. Complexity science. Let them eat complexity: the emperor's new toolkit. BMJ 2002; 324: 171. [PubMed][CrossRef]

Publisert: 25. januar 2019. Tidsskr Nor Legeforen. DOI: 10.4045/tidsskr.18.0724

Mottatt 18.9.2018, første revisjon innsendt 17.10.2018, godkjent 30.10.2018.

(C) Tidsskrift for Den norske legeforening 2020. Lastet ned fra tidsskriftet.no 